\title{
POTENSI DAN KENDALA DALAM PENGUATAN DAN PENUMBUHAN KELOMPOK PEMASARAN BAHAN OLAH KARET TERORGANISIR DI PROVINSI SUMATERA SELATAN
}

\author{
Potentials and Constraints in Strengthening and Developing the Organized Marketing \\ Group of Raw Rubber Materials in South Sumatera Province \\ Lina Fatayati SYARIFA, Dwi Shinta AGUSTINA*), \\ Aprizal ALAMSYAH dan Iman Satra NUGRAHA \\ Balai Penelitian Sembawa, Pusat Penelitian Karet \\ Jalan Raya Palembang - P. Balai KM 29 Palembang 30001 Sumatera Selatan \\ *Email: dwishinta_sbw@yahoo.com
}

Diterima : 1 Juli 2016 / Direvisi : 8 Agustus 2016 / Disetujui : 29 September 2016

\begin{abstract}
The organized marketing system has able to improve quality of raw rubber material and farmers' share. Therefore, it is needed founding to strengthen and develop the auction marketing system. Before conducting that, it is needed a research to identify the marketing groups, the constraints and the potential in developing the groups. The study was conducted by survey method. Location was selected purposively by choosing the location that was: 1) Farmers' group association/Village Cooperative Unit/Raw Rubber Material Processing and Marketing Unit that conduct auction market or partnerships; 2) Marketing groups which has not conducted an auction marketor partnerships; and 3) Location of Farmers' group association/Village Cooperative Unit/Raw Rubber Material Processing and Marketing Unit which was no longer active. Data collection was conducted by interview using a questionnaire to sample groups. The results showed that the most fundamental obstacles in strengthening the marketing group is lack of farmers' commitment to keep selling rubber by group, lack of awareness to maintain raw rubber material quality, and lack of transparency between board and members of groups. For this group, it is needed guidance and extension about organized marketing and technical guidance in improving quality of raw rubber material. The most fundamental supporting factors in strengthening the marketing group is a fair dealing between management board and members of group, as well as the activities that were bonding the members, such as: savings and loans, and supplying inputs or groceries for farmers.
\end{abstract}

\author{
Keywords: Raw rubber material; \\ strengthening; developing; \\ organized marketing group
}

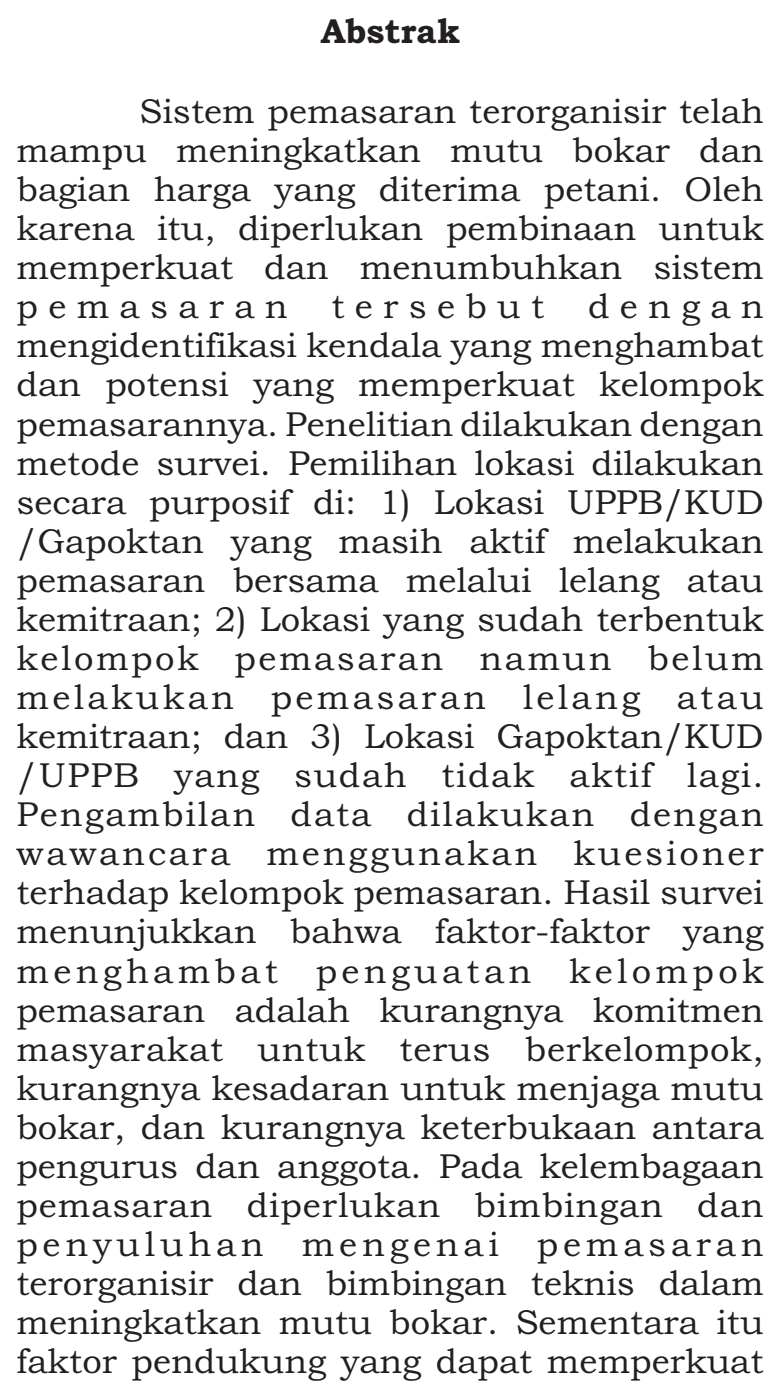


lembaga pemasaran adalah adanya keterbukaan antara pengurus dan anggota, dan adanya kegiatan yang bersifat dapat mengikat anggota seperti kegiatan simpan pinjam dan penyediaan saprodi atau sembako.

Kata kunci: Bokar; penguatan; penumbuhan; kelompok pemasaran terorganisir

\section{PENDAHULUAN}

Indonesia merupakan negara produsen dan pengekspor karet alam utama dunia setelah Thailand. Karet alam merupakan komoditas strategis karena kontribusinya terhadap penerimaan devisa negara (USD 7,3 Milyar), penyerapan tenaga kerja dan menjadi sumber pendapatan bagi 2 juta kepala keluarga tani di pedesaan. Perkebunan karet di Indonesia didominasi oleh perkebunan karet rakyat. Pada tahun 2012, perkebunan karet rakyat telah meliputi areal seluas 3 juta Ha atau sekitar $81 \%$ dari total areal karet nasional, dengan produksi sekitar $80 \%$ dari total produksi karet alam nasional (Badan Pusat Statistik [BPS], 2013).

Di Sumatera Selatan (Sumsel), karet alam merupakan salah satu komoditas ekspor unggulan yang memberikan kontribusi sangat besar terhadap penerimaan non migas, disamping peran strategis lainnya yaitu sebagai sumber pendapatan masyarakat, menyerap banyak tenaga kerja dan perannya terhadap kelestarian lingkungan. Data pada tahun 2012 menunjukkan bahwa luas areal karet di Sumatera Selatan telah mencapai 1,2 juta $\mathrm{Ha}$, dengan total produksi sekitar 850 ribu ton, dan hampir 500 ribu Kepala Keluarga (KK) atau $46 \%$ penduduk Sumsel menggantungkan hidupnya dari komoditas karet (Direktorat Jenderal Perkebunan [Ditjenbun], 2013; BPS Sumsel, 2012).

Seiring dengan meningkatnya permintaan dunia terhadap karet remah, jumlah pabrik karet di Sumatera Selatan terus meningkat hingga sekarang menjadi 27 pabrik. Kondisi ini menimbulkan persaingan dalam memperebutkan bahan olah karet (Bokar) antar pabrik, yang pada gilirannya memicu para petani untuk menyediakan bahan baku sebanyakbanyaknya tanpa memperhatikan aspek kualitas bokar. Pengawasan mutu yang lemah dan tidak adanya insentif harga terhadap mutu, menyebabkan petani mencampur bahan olah karet dengan kontaminan untuk menambahkan berat bokar, dengan harapan akan mendapatkan pendapatan yang tinggi dari penjualan bokar.

Kontaminan bisa menurunkan daya elastisitas karet, menurunkan kekuatan tarik, dan ketahanan sobek dari vulkanisatnya. Kontaminan yang sering terdapat di dalam bahan baku karet adalah pasir dan tatal. Untuk mengeluarkan zat-zat tersebut diperlukan serangkaian proses pencacahan dan pencucian yang banyak memerlukan air, listrik dan waktu proses. Selain itu, ditemukan pula kontaminan berupa limbah kompon dan limbah vulkanisat yang berasal dari barang jadi lateks seperti sisa-sisa karet busa, sarung tangan, balondan vulkanisat barang jadi lateks lainnya. Di tingkat pabrik, pekerjaan pemisahan kontaminan vulkanisat dari blanket atau lembaran sepenuhnya dilakukan secara manual, yang banyak memerlukan tenaga dan biaya ekstra. Pada produk ban, dampak dari kontaminan vulkanisat tersebut dapat menyebabkan ban sobek bahkan pecah atau meletus pada saat digunakan. Beberapa pabrik telah mengeluarkan langkah pencegahan dengan menolak penjualan bokar golongan lump atau sleb dari seseorang pedagang, jika pada sortasi awal ditemukan adanya kontaminan vulkanisat.

Melihat permasalahan tersebut maka perlu segera ditempuh upaya untuk memperbaiki daya saing karet nasional. Salah satu upaya yang telah dilakukan oleh pemerintah adalah mengeluarkan peraturan yaitu Peraturan Menteri Pertanian Nomor 38/Permentan/OT.140/8/2008 tentang Pedoman Pengolahan dan Pemasaran Bahan Olah Karet (BOKAR) (Kementerian Pertanian Republik Indonesia, 2008) dan Peraturan Menteri Perdagangan Nomor 53/MDAG/PER/10/2009 tentang Pengawasan Mutu Bahan Olah Komoditi Ekspor Standard Indonesian Rubber yang diperdagangkan (Kementerian Perdagangan Republik Indonesia, 2009) yang berlandaskan SNI Nomor 06-2047-2002 
tentang BOKAR dan Undang-Undang Nomor 18 Tahun 2004 tentang Perkebunan. Agar kebijakan tersebut dapat berjalan efektif perlu didukung oleh suatu gerakan yang bersifat nasional dalam bentuk Gerakan Nasional Bokar Bersih (GNBB). Salah satu tujuan GNBB adalah menghasilkan bokar bersih dan bermutu sesuai dengan persyaratan teknis yang berlaku, dan memperbaiki serta meningkatkan nilai pendapatan masing-masing pihak yang terkait secara proporsional dimulai dari tingkat petani, pedagang, industri pengolahan bokar hingga eksportir, sehingga karet Indonesia menjadi semakin mampu bersaing di pasar Internasional.

Dari hasil studi sebelumnya diperoleh informasi bahwa sosialisasi Peraturan Menteri Pertanian dan Menteri Perdagangan mengenai bokar bersih belum merata dilaksanakan di tingkat petani. Secara umum, sosialisasi peraturan tersebut hanya dilakukan sampai di tingkat pedagang perantara pada saat transaksi penjualan bokar di pabrik karet atau poolpool karet. Selanjutnya, pedagang menyampaikan informasi tersebut kepada petani. Namun, sebagian besar petani diantaranya masih ada yang belum mengetahui peraturan tersebut. Sebaliknya, meskipun sudah mengetahui, petani belum banyak yang melaksanakan peraturan itu, karena masih banyak pedagang yang menerima bokar berkualitas rendah (Syarifa, Agustina, \& Nancy, 2013).

Oleh karena itu, permasalahan pengolahan dan pemasaran karet yang menyebabkan rendahnya mutu bokar dan pendapatan petani masih banyak terjadi di beberapa wilayah di Sumatera Selatan. Hal ini terlihat dari tingkat kebersihan bokar, jenis pembeku, dan cara penyimpanan bokar yang sebagian besar belum memenuhi standar yang berlaku. Studi sebelumnya menunjukkan bahwa sistem pemasaran terorganisir atau lelang telah mampu meningkatkan mutu bokar dan bagian harga yang diterima petani (Nancy, Syarifa, Agustina, Alamsyah, \& Nugraha, 2012). Melalui pemasaran terorganisir, mutu bokar lebih baik dibandingkan pemasaran tradisional, baik dari aspek kebersihan, penyimpanan, tempat pembekuan, jenis pembeku, dan ketebalan bokar (Tabel 1).
Dengan tingginya mutu bokar yang dihasilkan, maka bagian harga yang diterima petani juga akan lebih besar. Hal ini dikarenakan, dengan menjual karet melalui pemasaran yang terorganisir, pabrik dapat memberikan insentif harga terhadap mutu karet yang dihasilkan petani. Dengan menerima penjualan karet melalui pemasaran bersama, pabrik bisa mendapatkan karet yang bermutu baik, yang tidak memerlukan biaya ekstra dalam pengolahannya menjadi karet remah.

Selain itu, sistem dan kelembagaan pemasaran bokar juga akan menentukan tingkat harga dan bagian harga yang diterima oleh petani (Tabel 2). Oleh karena itu, untuk wilayah-wilayah yang telah melakukan sistem pemasaran lelang, diperlukan pengawalan dan pembinaan untuk memperkuat sistem pemasaran lelang yang sudah ada. Sedangkan untuk wilayah-wilayah yang belum ada sistem pemasaran lelang, maka diperlukan upaya bagi penumbuhan kelompok-kelompok pemasaran lelang. Namun sebelum itu, perlu diteliti terlebih dahulu untuk mengidentifikasi potensi dan kendala yang ada dalam kelompok pemasaran yang dapat mendukung maupun menghambat berkembangnya kelompok-kelompok pemasaran, sehingga untuk tahapan lebih lanjut akan dapat diambil langkah-langkah yang tepat dalam upaya penguatan dan penumbuhan kelompok-kelompok pemasaran bokar terorganisir di Sumatera Selatan. Tulisan ini akan menguraikan kendala serta potensi pendukung bagi keberlangsungan kelompok pemasaran bokar terorganisir.

\section{BAHAN DAN METODE}

Kegiatan penelitian dilakukan di Provinsi Sumatera Selatan pada tahun 2013 menggunakan metode survei dengan mengidentifikasi kelompok-kelompok pemasaran serta mengidentifikasi masalah, kendala dan potensi yang menghambat maupun yang mendorong terbentuknya atau memperkuat sistem pemasaran bersama. Pemilihan lokasi dilakukan secara purposif meliputi: 
Tabel 1. Kondisi mutu bokar pada pasar tradisional dan pasar terorganisir Table 1. Quality of raw rubber material at traditional and organized markets

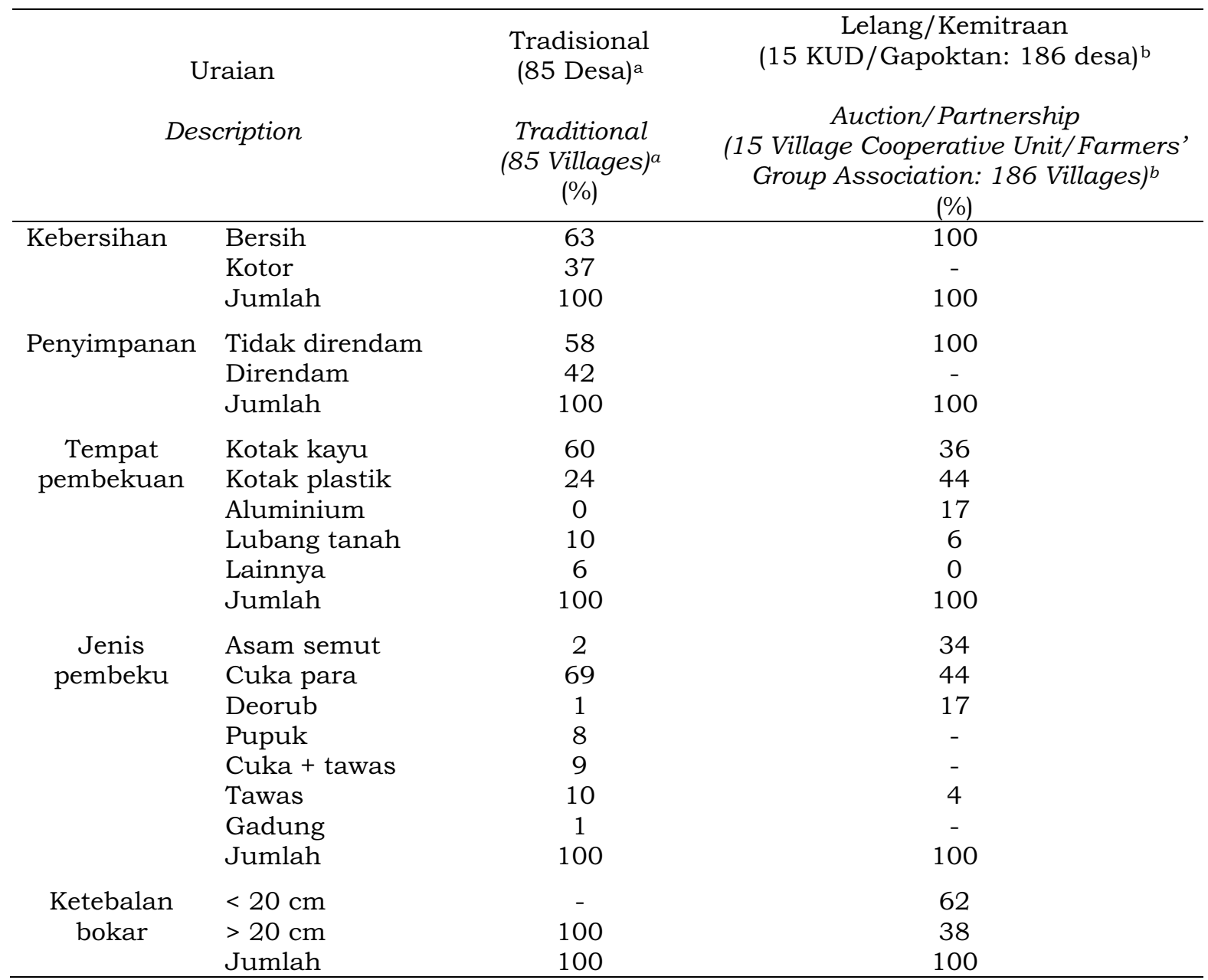

Sumber (Source) : ${ }^{a}$ Syarifa et al. (2011) ; Nancy et al. (2012)

1. Lokasi yang telah terbentuk pemasaran bersama melalui lelang atau kemitraan yaitu Unit Pengolahan dan Pemasaran Bersama (UPPB), Koperasi Unit Desa (KUD) lelang dan Gabungan Kelompok Tani (Gapoktan) yang masih aktif, selanjutnya disebut pemasaran terorganisir.

2. Lokasi yang sudah terbentuk kelompok pemasaran namun belum melakukan pemasaran lelang atau kemitraan.

3. Lokasi Gapoktan, KUD lelang atau UPPB yang telah tidak aktif.

Dari ketiga kriteria tersebut diperoleh 16 buah contoh KUD, Gapoktan, UPPB, dan Kelompok tani pemasaran bokar terorganisir sebagaimana disajikan dalam Tabel 3.
Selanjutnya pengambilan data dilakukan dengan melakukan wawancara langsung terhadap pengurus maupun petani yang menjadi anggota KUD/Gapoktan/UPPB / Kelompok tani pemasaran bokar. Data yang dikumpulkan selanjutnya ditabulasi dan dianalisa secara deskriptif.

\section{HASIL DAN PEMBAHASAN}

\section{Mutu Bokar dan Bagian Harga Petani}

Hasil survei pada contoh kelompok pemasaran bokar yang diamati, menunjukkan bahwa sebagian besar petani menghasilkan bokar dalam bentuk sleb dan lump. Dari pengamatan secara visual, umumnya petani telah menghasilkan sleb 
Tabel 2. Sistem pemasaran dan bagian harga yang diterima petani Table 2. Marketing system and farmes' share

\begin{tabular}{llcc}
\hline \multicolumn{1}{c}{$\begin{array}{c}\text { Sistem pemasaran } \\
\text { Marketing system }\end{array}$} & $\begin{array}{c}\text { Jenis } \\
\text { bokar } \\
\text { Type of } \\
\text { rubber raw } \\
\text { material }\end{array}$ & $\begin{array}{c}\text { Bagian harga } \\
\text { petani } \\
\text { Farmers' share } \\
\text { (\% FOB SIR20) }\end{array}$ & $\begin{array}{c}\text { Tahun } \\
\text { penelitian } \\
\text { Year of } \\
\text { Study }\end{array}$ \\
\hline A. Tradisional & & & \\
- Lokasi jauh & Sleb tebal & $55-70$ & 1993 \\
- Lokasi dekat & Sleb tebal & $70-80$ & 1993 \\
B. Terorganisir & & & \\
- Lelang di Panerokan Jambi & Sleb tipis & 87 & 1995 \\
- Lelang di Kedaton (OKU, Sumsel) & Sleb tebal & 82 & 2000 \\
- Lelang di Pampangan (OKI, Sumsel) & Sleb tebal & 83 & 2002 \\
- Lelang di Pasaman (Sumbar) & Sleb tebal & 76 & 2005 \\
- Lelang di Bungo dan Tebo (Jambi) & Sleb tebal & 76 & 2005 \\
- Kemitraan Inti-Plasma (PIR-Mini Estate) & Sleb lump & 82 & 1992 \\
- Kemitraan TCSDP Sekayu Sumatera Selatan & Sleb tipis & 85 & 1996 \\
- Lelang di PIR Batumarta (OKU, Sumsel) & Sleb tebal & 84 & 2000 \\
- Lelang KUD Serasan Jaya & Sleb tipis & $>90$ & 2012 \\
- Lelang KUD Berkat & Sleb tipis & $>90$ & 2012 \\
- Lelang KUD Mufakat & Sleb tipis & $>90$ & 2012 \\
\hline Sumber (Source): Hendratno et al. (2009); Nancy & et al. (2012). & &
\end{tabular}

Tabel 3. Data jumlah contoh dan diskripsi KUD/Gapoktan/UPPB/Kelompok tani kelompok pemasaran bokar terorganisir di Sumatera Selatan

Table 3. Data of number of sampling and description of Village Cooperative Unit / Farmers' Group Association /Unit of raw rubber material processing \& marketing / Farmers' Group in South Sumatra

\begin{tabular}{|c|c|c|c|c|c|c|c|}
\hline \multirow{2}{*}{$\begin{array}{c}\text { KUD/Gapoktan/ } \\
\text { UPPB/Kelompok tani } \\
\\
\text { Village Cooperative Unit/ } \\
\text { Farmers' Group } \\
\text { Association/ Unit of raw } \\
\text { rubber material } \\
\text { processing\&marketing/ } \\
\text { Farmers' Group }\end{array}$} & \multirow[b]{2}{*}{$\begin{array}{c}\text { Kabupaten } \\
\text { District }\end{array}$} & \multirow[b]{2}{*}{$\begin{array}{c}\text { Masa } \\
\text { aktif } \\
\text { (tahun) }\end{array}$} & \multirow[b]{2}{*}{$\begin{array}{l}\text { Status } \\
\text { Status }\end{array}$} & \multicolumn{2}{|c|}{$\begin{array}{l}\text { Anggota } \\
\text { Member }\end{array}$} & \multirow{2}{*}{$\begin{array}{l}\text { Volume } \\
\text { Bokar } \\
\text { per bulan } \\
\text { (ton) } \\
\\
\text { Volume of } \\
\text { raw } \\
\text { rubber } \\
\text { material } \\
\text { per } \\
\text { month } \\
\text { (tons) }\end{array}$} & \multirow[b]{2}{*}{$\begin{array}{l}\text { Periode Lelang } \\
\text { Period of auction }\end{array}$} \\
\hline & & & & $\begin{array}{c}\text { Awal } \\
\text { Beginning }\end{array}$ & $\begin{array}{l}\text { Sekarang } \\
\text { Current }\end{array}$ & & \\
\hline Serasan Jaya & Muara Enim & 25 & Aktif & 549 & 1.200 & 14.700 & Dua kali/bulan \\
\hline Berkat & Muara Enim & 25 & Aktif & $\mathrm{Na}$ & 5.000 & 6.800 & Dua kali/bulan \\
\hline Mufakat Jaya & Muara Enim & 25 & Aktif & 44 & 1.480 & 600 & Dua kali/bulan \\
\hline Maju Bersama & Muara Enim & 7 & Aktif & 50 & 75 & 15 & Satu kali/bulan \\
\hline Sukajadi & Muara Enim & na & Kelompok & 100 & 100 & 20 & Setiap minggu \\
\hline Bina Karya & Prabumulih & 5 & Aktif & 100 & 350 & 320 & Satu kali/bulan \\
\hline Manunggal Jaya & Prabumulih & 13 & Aktif & 300 & 1.500 & 600 & Dua kali/bulan \\
\hline Balam Sejahtera & Prabumulih & 8 & Aktif & 30 & 108 & 150 & Satu kali/bulan \\
\hline Karet Setia Bersatu & Ogan Komering Ulu & 4 & Aktif & 53 & 400 & 200 & Setiap minggu \\
\hline Wana lestari & Ogan Ilir & 13 & Aktif & 25 & 190 & 60 & Dua kali/bulan \\
\hline Ngerawan Indah L & Ogan Ilir & 2 & Aktif & 100 & 359 & 68 & Setiap minggu \\
\hline Cahaya Bersinar & Ogan Ilir & 8 & Aktif & 30 & 150 & 60 & Dua kali/bulan \\
\hline Lavender & Banyuasin & 4 & Aktif & 7 & 115 & 24 & Setiap minggu \\
\hline Harmas & Banyuasin & 3 & Aktif & 65 & 125 & 25 & Setiap minggu \\
\hline Kopmumasgoro & Banyuasin & 11 & Aktif & 15 & 100 & 24 & Setiap minggu \\
\hline Sungai Bungin & Ogan Komering Ilir & 2 & Tidak aktif & 110 & 20 & na & na \\
\hline
\end{tabular}

Keterangan (Remaks): na = data tidak tersedia (data is not available) 
bersih, dengan kadar karet kering (KKK) bokar rata-rata yang tertinggi dihasilkan oleh kelompok petani di KUD Serasan Jaya (65-85\%) untuk umur simpan bokar selama 1 bulan. Sementara KKK bokar yang paling rendah $(40 \%)$ untuk umur simpan yang sama dihasilkan oleh kelompok tani di KUD Karet Setia Bersatu, Kabupaten OKU. Dari beberapa kelompok pemasaran, bagian harga yang diterima oleh petani telah mencapai lebih dari 80\% FOB (Tabel 4). Hal ini sejalan dengan hasil penelitian yang dilakukan oleh James, Alamsyah dan Saidin (2015) bahwa petani yang memasarkan produk karetnya melalui pemasaran terorganisir akan mendapatkan bagian harga yang diterima petani lebih tinggi dibandingkan dengan pemasaran yang tidak terorganisir.

Dilihat dari cara pengolahan bokar (Tabel 5), anggota kelompok sudah cukup banyak yang menggunakan asam semut dan deorub (31\%). Penggunaan asam semut banyak dilakukan oleh kelompok pemasaran di Kabupaten Ogan Ilir. Namun, sebagian besar anggota kelompok di wilayah lainnya masih banyak menggunakan bahan pembeku yang tidak direkomendasikan yaitu asam sulfat (60\%) yang lebih dikenal masyarakat dengan sebutan cuka para. Selain cuka para, petani juga masih menggunakan tawas dan plozi. Padahal, secara umum sleb yang digumpalkan dengan pembeku yang tidak dianjurkan memiliki plastisitas karet yang rendah yang ditunjukkan oleh nilai plastisitas awal (Po) dan indeks ketahanan plastisitas (PRI) yang di bawah standar SIR (Purbaya, Sari, Chessa, \& Mutia, 2011). Zat pembeku yang berkualitas rendah masih banyak di tingkat petani dikarenakan jenis-jenis pembeku tersebut paling banyak dan mudah diperoleh di pasaran dengan harga yang lebih murah dibandingkan dengan pembeku anjuran seperti asam semut dan deorub yang hanya bisa diperoleh melalui koperasi atau Dinas Perkebunan. Oleh karena itu, masih diperlukan perbaikan terhadap penggunaan koagulan (pembeku) yang dianjurkan di tingkat kelompok-kelompok pemasaran bokar tersebut.

Tabel 4. Kebersihan, Kadar Karet Kering (KKK) bokar dan bagian harga petani

Table 4. Cleanness, Dry Rubber Content (DRC) of raw rubber material and farmers' share

\begin{tabular}{|c|c|c|c|c|}
\hline $\begin{array}{c}\text { KUD/Gapoktan/ } \\
\text { UPPB/Kelompok tani } \\
\text { Village Cooperative Unit/ } \\
\text { Farmers' Group Association/ Unit } \\
\text { of raw rubber material processing } \\
\text { and marketing/ Farmers' Group }\end{array}$ & $\begin{array}{l}\text { Umur simpan } \\
\text { bokar } \\
\text { Storing age of raw } \\
\text { rubber material }\end{array}$ & $\begin{array}{c}\text { Kualitas } \\
\text { bokar } \\
\text { Quality of raw } \\
\text { rubber } \\
\text { material }\end{array}$ & $\begin{array}{c}\mathrm{KKK} \\
\mathrm{DRC} \\
(\%)\end{array}$ & $\% \mathrm{FOB}$ \\
\hline Serasan Jaya & 1 bulan & Bersih & $65-85$ & 75 \\
\hline Berkat & 1 bulan & Bersih & $58-60$ & 94 \\
\hline Mufakat Jaya & 1 bulan & Bersih & 55 & 92 \\
\hline Maju Bersama & 1 bulan & Bersih & 60 & 92 \\
\hline Bina Karya & 1 bulan & Bersih & 60 & 94 \\
\hline Manunggal Jaya & 1 bulan & Bersih & 58 & 88 \\
\hline Balam Sejahtera & 1 bulan & Bersih & 59 & 95 \\
\hline Karet Setia Bersatu & 1 minggu & Bersih & 40 & na \\
\hline Wana lestari & 1 minggu & Bersih & 52 & 76 \\
\hline Ngerawan Indah Laut & 1 minggu & Bersih & 50 & 88 \\
\hline Cahaya Bersinar & 2 minggu & Bersih & $54-56$ & 74 \\
\hline Lavender & 1 minggu & Bersih & 48 & 84 \\
\hline Harmas & 1 minggu & Bersih & 58 & na \\
\hline Kopmumasgoro & 1 minggu & Bersih & 48 & na \\
\hline
\end{tabular}

Keterangan (Remaks): na = data tidak tersedia (data is not available) 
Tabel 5. Jenis pembeku karet yang digunakan

Table 5. Type of rubber coagulant were used

\begin{tabular}{|c|c|c|c|c|c|c|c|}
\hline \multirow{2}{*}{$\begin{array}{c}\text { KUD/Gapoktan/ } \\
\text { UPPB/Kelompok } \\
\text { Village Cooperative } \\
\text { Unit/Farmers' Group } \\
\text { Association/Unit of raw } \\
\text { rubber material processing } \\
\text { and marketing/Farmers' } \\
\text { Group }\end{array}$} & \multirow{2}{*}{$\begin{array}{l}\text { Lokasi } \\
\text { Location }\end{array}$} & \multicolumn{6}{|c|}{$\begin{array}{c}\text { Jenis pembeku } \\
\text { Type of coagulant } \\
(\%)\end{array}$} \\
\hline & & $\begin{array}{l}\text { Asam } \\
\text { Semut } \\
\text { Formic } \\
\text { acid }\end{array}$ & $\begin{array}{l}\text { Cuka Para } \\
\text { Sulfuric } \\
\text { acid }\end{array}$ & Deorub & $\begin{array}{c}\text { Tawas } \\
\text { Alum }\end{array}$ & Plozi & $\begin{array}{c}\text { Jumlah } \\
\text { Total }\end{array}$ \\
\hline Serasan Jaya & Muara Enim & 30 & 70 & 0 & 0 & 0 & 100 \\
\hline Berkat & Muara Enim & 0 & 100 & 0 & 0 & 0 & 100 \\
\hline Mufakat Jaya & Muara Enim & 0 & 100 & 0 & 0 & 0 & 100 \\
\hline Maju Bersama & Muara Enim & 0 & 100 & 0 & 0 & 0 & 100 \\
\hline Bina Karya & Prabumulih & 0 & 100 & 0 & 0 & 0 & 100 \\
\hline Manunggal Jaya & Prabumulih & 0 & 100 & 0 & 0 & 0 & 100 \\
\hline Balam Sejahtera & Prabumulih & 0 & 80 & 20 & 0 & 0 & 100 \\
\hline Karet Setia Bersatu & OKU & 0 & 0 & 0 & 20 & 80 & 100 \\
\hline Wana lestari & Ogan Ilir & 99 & 1 & 0 & 0 & 0 & 100 \\
\hline Ngerawan Indah Laut & Ogan Ilir & 100 & 0 & 0 & 0 & 0 & 100 \\
\hline Cahaya Bersinar & Ogan Ilir & 100 & 0 & 0 & 0 & 0 & 100 \\
\hline Lavender & Banyuasin & 0 & 60 & 30 & 10 & 0 & 100 \\
\hline Harmas & Banyuasin & 0 & 3 & 92 & 0 & 5 & 100 \\
\hline Kopmumasgoro & Banyuasin & 0 & 90 & 0 & 10 & 0 & 100 \\
\hline Sungai Bungin & OKI & 0 & 100 & 0 & 0 & 0 & 100 \\
\hline Rata-rata & & 22 & 60 & 9 & 3 & 6 & 100 \\
\hline
\end{tabular}

Dilihat dari cara penyimpanan dan tempat pencetakan bokar yang dilakukan oleh anggota kelompok umumnya sudah baik (Gambar 1), hal ini terlihat dari tidak ada lagi bokar yang direndam serta telah m e ng gu n a k c e tak a n y a n g direkomendasikan (94\%) antara lain seperti kotak kayu, kotak plastik dan kotak aluminium (Tabel 6).

\section{Potensi dan Kendala dalam Penguatan dan Penumbuhan Kelompok Pemasaran Terorganisir}

Selanjutnya pengamatan dilakukan terhadap kendala yang menghambat serta potensi yang mendukung keberlangsungan kelompok pemasaran bersama.Hasil survei menunjukkan bahwa faktor-faktor kendala dan potensi pendukung yang ada pada kelompok pemasaran dapat diklasifikasikan ke dalam tiga kategori yaitu:

a. Kelompok KUD/Gapoktan/UPPB berada pada lokasi yang kelompok pemasarannya belum berkembang dan kelompok yang pernah ada namun sudah tidak aktif lagi

Berbagai hambatan yang memiliki potensi mengancam keberlangsungan kelompok pemasaran pada lokasi yang belum berkembang, sebagai contoh Kelompok Karet Setia Bersatu di Kabupaten
OKU dan Gapoktan Sungai Bungin di Kabupaten OKI, antara lain:

1. Para anggota kelompok tidak saling memiliki komitmen untuk menjual bokar secara berkelompok.

2. Kelompok menghadapi persaingan dengan tengkulak dalam hal penetapan harga jual dan pelayanan khususnya dalam peminjaman uang kepada petani. Umumnya kelompok ini memiliki keterbatasan modal.

3. Para anggota masih ada yang memiliki keterikatan dengan tengkulak dalam hal hubungan kekeluargaan maupun hutang.

4. Para anggota kurang memiliki komitmen untuk mematuhi aturan kelompok dalam hal menjaga mutu bokar. Hal ini dapat menyebabkan harga bokar yang diterima menjadi rendah, dan pada gilirannya menyebabkan anggota kembali memilih tengkulak yang menjanjikan harga yang lebih tinggi dibandingkan harga.

5. Pengurus masih kurang terbuka terhadap anggota dalam hal manajemen keuangan, sehingga menyebabkan anggota membentuk kelompok baru dan atau menjual bokar ke tengkulak. 

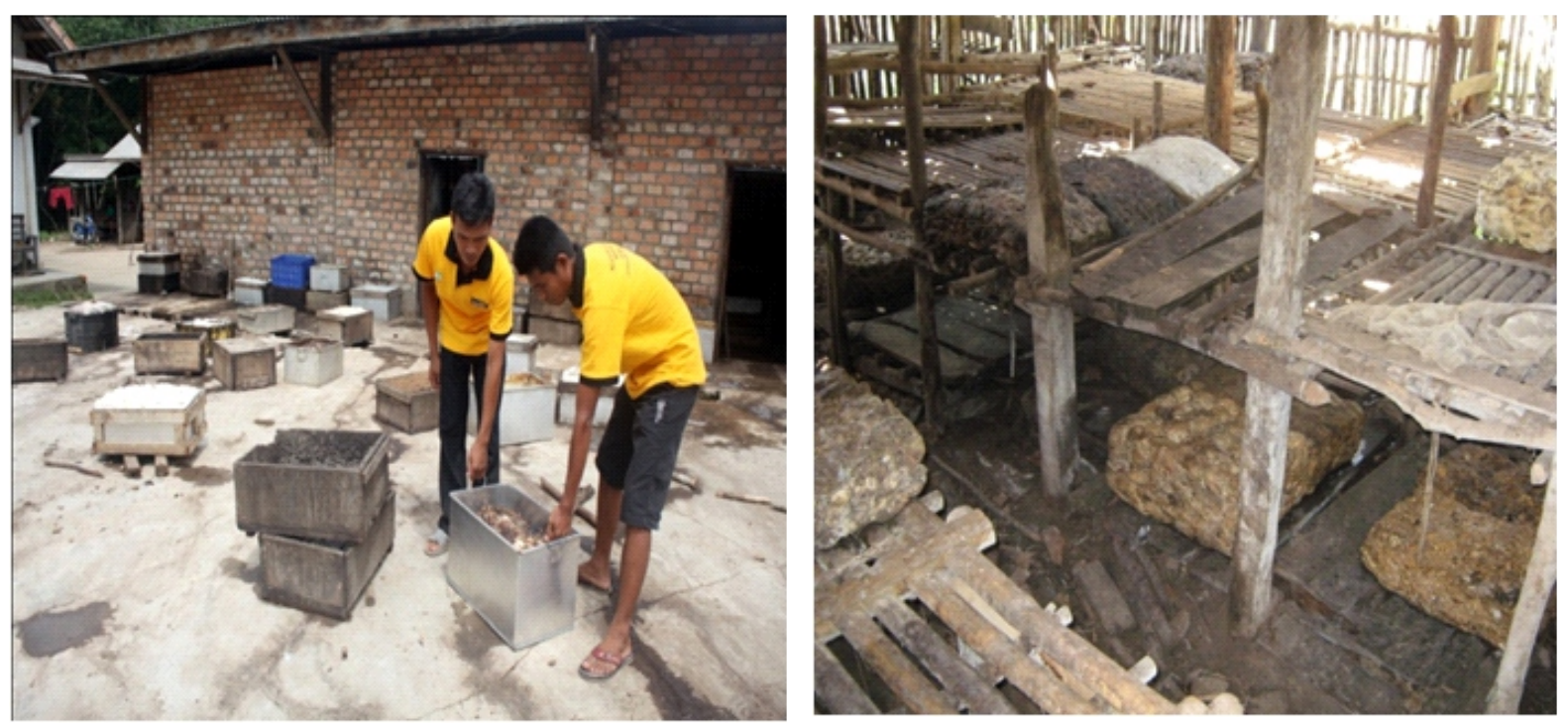

Gambar 1. Cara pencetakan dan penyimpanan bokar

Figure 1. Method of raw rubber material mould and storage

Tabel 6. Tempat pencetakan dan penyimpanan bokar Table 6. Mold and storage of raw rubber material

\begin{tabular}{|c|c|c|c|c|c|c|c|c|c|c|}
\hline \multirow{2}{*}{$\begin{array}{l}\text { KUD/Gapoktan/ } \\
\text { UPPB/Kelompok } \\
\text { Village Cooperative } \\
\text { Unit/ Farmers' Group } \\
\text { Association/ Unit of } \\
\text { raw rubber material } \\
\text { processing and } \\
\text { marketing/ Farmers' } \\
\text { Group }\end{array}$} & \multicolumn{5}{|c|}{$\begin{array}{c}\text { Tempat pencetakan bokar } \\
\text { Raw rubber material mold } \\
(\%)\end{array}$} & \multicolumn{5}{|c|}{$\begin{array}{c}\text { Tempat penyimpanan bokar } \\
\text { The storage of raw rubber material } \\
(\%)\end{array}$} \\
\hline & $\begin{array}{l}\text { Kotak } \\
\text { kayu } \\
\text { Wooden } \\
\text { box }\end{array}$ & $\begin{array}{l}\text { Kotak } \\
\text { plastik } \\
\text { Plastics } \\
\text { box }\end{array}$ & $\begin{array}{l}\text { Lubang } \\
\text { tanah } \\
\text { Ground } \\
\text { hole }\end{array}$ & $\begin{array}{l}\text { Aluminium } \\
\text { Aluminium }\end{array}$ & Jumlah & $\begin{array}{c}\text { Gudang } \\
\text { Warehouse }\end{array}$ & $\begin{array}{l}\text { Kebun } \\
\text { Field }\end{array}$ & $\begin{array}{l}\text { Ruang } \\
\text { terbuka } \\
\text { Open } \\
\text { space }\end{array}$ & $\begin{array}{l}\text { Kolam } \\
\text { Pond }\end{array}$ & Jumlah \\
\hline Serasan Jaya & 0 & 70 & 0 & 30 & 100 & 100 & 0 & 0 & 0 & 100 \\
\hline Berkat & 60 & 40 & 0 & 0 & 100 & 100 & 0 & 0 & 0 & 100 \\
\hline Mufakat Jaya & 20 & 80 & 0 & 0 & 100 & 100 & 0 & 0 & 0 & 100 \\
\hline Maju Bersama & 0 & 0 & 0 & 100 & 100 & 0 & 0 & 100 & 0 & 100 \\
\hline Bina Karya & 50 & 50 & 0 & 0 & 100 & 100 & 0 & 0 & 0 & 100 \\
\hline Manunggal Jaya & 80 & 20 & 0 & 0 & 100 & 0 & 0 & 100 & 0 & 100 \\
\hline Balam Sejahtera & 0 & 50 & 0 & 50 & 100 & 0 & 0 & 100 & 0 & 100 \\
\hline Karet Setia Bersatu & 0 & 100 & 0 & 0 & 100 & 0 & 0 & 100 & 0 & 100 \\
\hline Wana lestari & 0 & 0 & 0 & 100 & 100 & 100 & 0 & 0 & 0 & 100 \\
\hline Ngerawan Indah Laut & 15 & 35 & 0 & 50 & 100 & 0 & 0 & 100 & 0 & 100 \\
\hline Cahaya Bersinar & 5 & 5 & 90 & 0 & 100 & 0 & 0 & 100 & 0 & 100 \\
\hline Lavender & 0 & 100 & 0 & 0 & 100 & 0 & 0 & 100 & 0 & 100 \\
\hline Harmas & 0 & 100 & 0 & 0 & 100 & 0 & 0 & 100 & 0 & 100 \\
\hline Kopmumasgoro & 0 & 100 & 0 & 0 & 100 & 0 & 0 & 100 & 0 & 100 \\
\hline Sungai Bungin & 20 & 40 & 0 & 40 & 100 & 0 & 0 & 100 & 0 & 100 \\
\hline Rata-rata & 17 & 53 & 6 & 25 & 100 & 33 & $\mathbf{0}$ & 67 & 0 & 100 \\
\hline
\end{tabular}


b. Kelompok KUD/Gapoktan/UPPB yang telah berjalan kurang dari 10 tahun dan berada pada wilayah kelompok pemasaran yang telah berkembang

$\mathrm{K}$ e 1 o m p o $\mathrm{k}$ p e m a s a $\mathrm{r}$ a $n$ KUD/Gapoktan/UPPB yang yang telah berjalan kurang dari 10 tahun dan lokasinya berada pada wilayah yang terdapat kelompok pemasaran yang telah berkembang umumnya berada di Kota Prabumulih, Kabupaten Banyuasin dan Kabupaten Ogan Ilir. Pada wilayah tersebut umumnya kendala yang menghambat bagi keberlangsungan kelompok antara lain adanya persaingan antara kelompokkelompok pemasaran dalam harga dan pelayanan.

\section{Persaingan dalam harga}

- Para anggota kurang memiliki komitmen untuk mematuhi aturan kelompok dalam hal menjaga mutu bokar. Akibatnya, dengan menjual karet dengan mutu yang rendah, harga bokar yang diterima menjadi rendah, dan hal inilah yang menyebabkan anggota kembali memilih kelompok lain yang menjanjikan harga yang lebih tinggi dibandingkan kelompok sebelumnya.

- Pihak pembeli bokar tidak memberikan apresiasi terhadap bokar bersih yang dihasilkan, sehingga anggota kelompok tidak tertarik membuat bokar bersih.

- Para pedagang masih bisa menguasai harga, karena disinyalir para pedagang telah bersepakat untuk bergiliran memenangkan tender.

- Kelompok masih memiliki kesulitan untuk mendatangkan peserta tender yang lebih banyak, sehingga posisi tawar kelompok masih tertekan oleh pedagang.

\section{Persaingan dalam pelayanan}

- Pengurus kelompok harus menyiapkan uang kas sebagai modal pinjaman untukanggota.
- Pengurus kelompok memiliki keterbatasan modal untuk melakukan pembayaran hasil penjualan bokar ke anggota secara langsung atau tunai.

- Pembeli masih melakukan kecurangan dalam penimbangan, yang dapat menyebabkan kehilangan kepercayaan anggota terhadap kelompok.

Disamping kendala dan hambatan, terdapat potensi yang mendukung keberlangsungan kelompok antara lain:

- Sejak awal masyarakat sudah memiliki komitmen yang kuat untuk memasarkan bokar secara berkelompok, yang pada akhirnya membuat mereka sepakat untuk membentuk kelompok pemasaran.

- Dalam pelaksanaannya, kelompok harus memberlakukan pengawasan secara ketat terhadap mutu bokar dengan menetapkan kriteria pengolahan bokar yang telah disepakati sebelumnya oleh pihak pengurus dan anggota kelompok.

- K e 1 o m p o k s e b a i k n y a memberlakukan simpanan wajib dan simpanan pokok anggota sebagai modal untuk simpan pinjam anggota.

- Selain untuk simpan pinjam, modal juga disisihkan untuk menyediakan kebutuhan sembako dan saprodi bagi anggota.

- Gapoktan bisa memanfaatkan bantuan pemerintah dalam hal pemberian bantuan bibit kepada anggota.

- Dalam kelompok perlu dibangun keterbukaan antara pengurus dan anggota terutama dalam hal manajemen keuangan kelompok atau koperasi.

- Kelompok memberlakukan aturanaturan pemasaran yang adil bagi anggota kelompok maupun pedagang berdasarkan keputusan rapat anggota (Gambar 2). 
c. Kelompok KUD/Gapoktan/UPPB yang telah berjalan lebih dari 10 tahun

Di Kabupaten Muara Enim dan Prabumulih terdapat kelompok-kelompok pemasaran yang telah berjalan lebih dari 10 tahun antara lain KUD Serasan Jaya, KUD Berkat, KUD Mufakat Jaya dan KUD Manunggal Jaya. KUD tersebut tidak banyak menghadapi permasalahan berarti yang akan mengancam keberlangsungan kelompok. Permasalahan yang umum terjadi adalah persaingan antar KUD dalam hal pemberian harga maupun pelayanan. Persaingan antara kelompok dengan tengkulak hampir tidak pernah terjadi, karena masyarakat umumnya sudah menjadi anggota KUD. Dari KUD tersebut dapat diidentifikasi potensi pendukung yang memperkuat keberlangsungan KUD antara lain:

1. Masyarakat telah memiliki komitmen yang kuat untuk menjual karet secara berkelompok. Umumnya masyarakat disekitar KUD telah mengerti keuntungan menjual bokar secara berkelompok.

2. Masyarakat sudah memiliki kesadaran untuk menjaga mutu bokar.

3. KUD memberlakukan simpanan wajib dan simpanan pokok anggota, sebagai modal bagi usaha simpan pinjam kepada anggota.

4. Pengurus KUD selalu membangun keterbukaan terhadap para pengurus TPK (Tempat Pengumpulan Karet) yang menjadi anggota KUD.

5. Pengurus KUD melakukan pembagian keuntungan pemasaran bokar secara adil terhadap pengurus TPK.

6. Para pengurus KUD selalu melakukan pendekatan secara pribadi untuk mengikat keanggotaan TPK-TPK yang sudah ada.
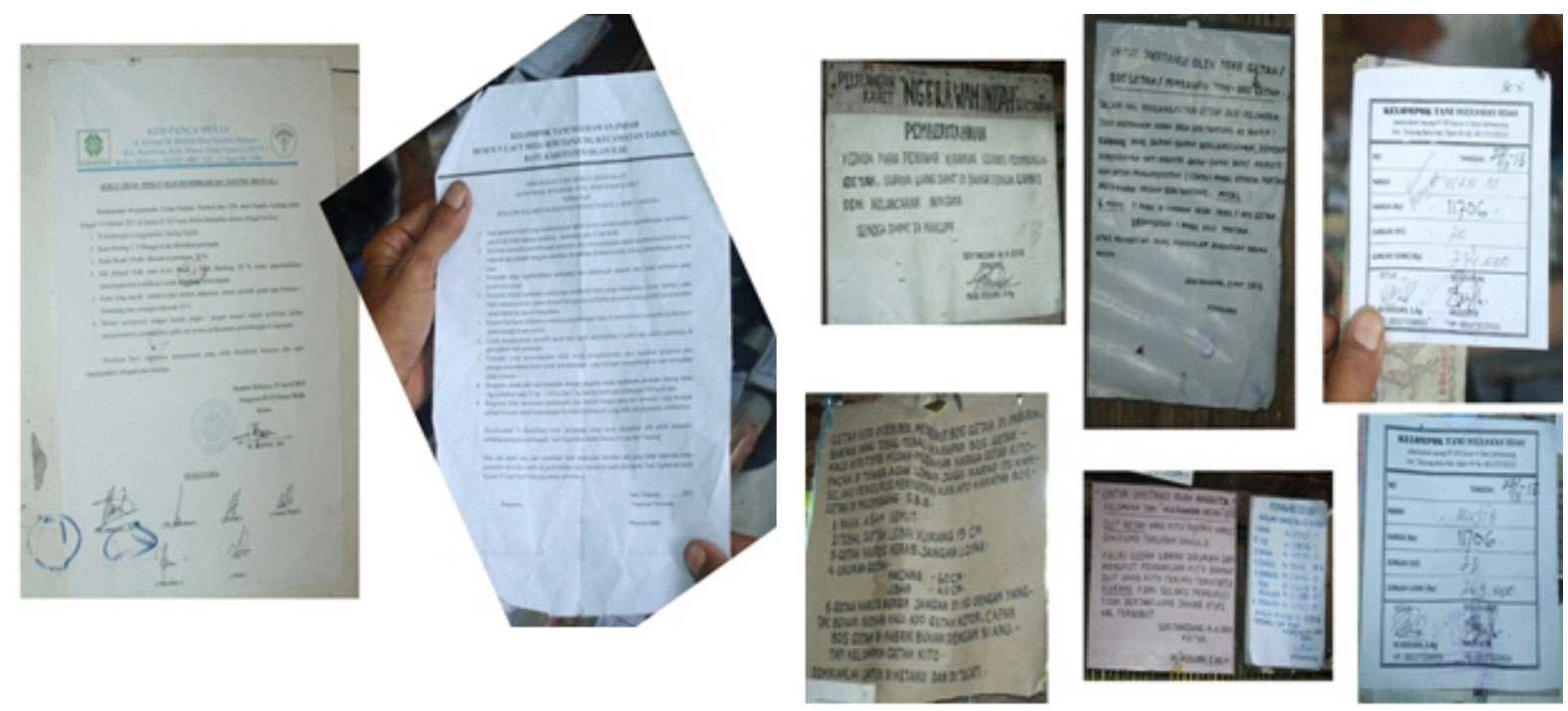

Gambar 2. Berbagai peraturan yang ditetapkan oleh kelompok sesuai kesepakatan anggota Figure 2. Various regulations established by the appropriate members group deal 


\section{KESIMPULAN}

Dari hasil penelitian dapat diidentifikasi berbagai kendala yang dapat menghambat pelaksanaan sistem pemasaran bersama serta potensi yang mendukung penguatan dan penumbuhan kelompok pemasaran bokar bersama. Hambatan bagi penguatan kelompok pemasaran adalah kurangnya komitmen masyarakat untuk terus berkelompok, kurangnya kesadaran untuk menjaga mutu bokar, serta kurangnya keterbukaan antara pengurus dan anggota. Pada kelembagaan pemasaran tersebut diperlukan bimbingan dan penyuluhan mengenai pemasaran terorganisir dan bimbingan teknis dalam meningkatkan mutu bokar. Sementara itu berbagai potensi pendukung yang memperkuat kelompok pemasaran adalah adanya keterbukaan antara pengurus dan anggota, dan adanya kegiatan pelayanan yang bersifat dapat mengikat anggota seperti kegiatan simpan pinjam dan penyediaan saprodi atau sembako. Untuk meningkatkan pelayanan tersebut diperlukan peningkatan kerjasama antara pihak KUD dengan lembaga peminjam modal (Bank).

\section{UCAPAN TERIMA KASIH}

Ucapan terima kasih disampaikan kepada para pengurus UPPB /KUD /Gapoktan Karet di Provinsi Sumatera Selatan yang telah memberikan bantuan data dan informasi terkait kegiatan penelitian ini.

\section{DAFTAR PUSTAKA}

Badan Pusat Statistik. (2013). Statistik Karet Indonesia 2013. Jakarta, Indonesia: BPS.

Badan Pusat Statistik Provinsi Sumatera Selatan. (2012). Penduduk. Palembang, Indonesia: BPS Provinsi Sumatera Selatan.
Direktorat Jenderal Perkebunan. (2013). Statistik Perkebunan Indonesia. Karet 2011-2012. Jakarta, Indonesia: Ditjenbun.

James, S. P., Alamsyah, Z., \& Saidin. (2015). Analisis efektivitas pasar lelang karet di Kabupaten Bungo Provinsi Jambi. Jurnal Sosio Ekonomika Bisnis, 18(1), 32-42.

Kementerian Perdagangan Republik Indonesia. (2009). Peraturan Menteri Perdagangan Nomor 53/2009. Pengawasan Mutu Bahan Olah Komoditi Ekspor Standard Indonesian Rubber yang Diperdagangkan. Jakarta, Indonesia: Kementerian Perdagangan Republik Indonesia.

Kementerian Pertanian Republik Indonesia. (2008). Peraturan Menteri Pertanian Nomor 38/2008. Pedoman Pengolahan dan Pemasaran Bahan Olah Karet (Bokar).Jakarta, Indonesia: Kementerian Pertanian Republik Indonesia.

Hendratno, S., Nancy, C., Supriadi, M., \& Anwar, C. (2009). Pemasaran bokar Dalam Saptabina Usahatani Karet Rakyat. Edisi Kelima. (p. 117-123). Palembang, Indonesia: Balai Penelitian Sembawa.

Nancy, C., Syarifa, L. F., Agustina, D. S., Alamsyah, A., \& Nugraha, I. S.(2012). Pengembangan pemasaran bahan olah karet di Provinsi Sumatera Selatan. Palembang, Indonesia: Dinas Perkebunan Provinsi Sumatera Selatan dan Balai Penelitian Sembawa.

Purbaya, M., Sari, T. I., Chessa, A. S., \& Mutia, T. F. (2011). Pengaruh beberapa jenis bahan penggumpal lateks dan hubungannya dengan susut bobot, kadar karet kering dan plastisitas. Prosiding Seminar Nasional AvoER ke-3 (p. 351-357). Palembang, Indonesia: Fakultas Teknik Universitas Sriwijaya. 
Syarifa, L. F., Agustina, D. S., \& Nancy, C. (2011). Evaluasi tingkat adopsi klon dan mutu bahan olah karet rakyat (bokar) di Provinsi Sumatera Selatan. Palembang, Indonesia: Balai Penelitian Sembawa.
Syarifa, L. F., Agustina, D. S., \& Nancy, C. (2013). Evaluasi pengolahan dan mutu bahan olah karet rakyat (Bokar) di tingkat petani karet di Sumatera Selatan. Jurnal Penelitian Karet, 31(2), 139-148. 